\title{
STATISTICAL ANALYSIS OF RESULTS OBTAINED IN THE HARDENING SURFACE OF THE METAL POWDER MATERIALS WITH OPTICAL RADIATION IMPULSES
}

\author{
Ioan VIRCA \\ virca_ioan@yahoo.com \\ “NICOLAE B̆̆LCESCU” LAND FORCES ACADEMY, SIBIU, ROMANIA
}

\section{ABSTRACT}

The paper presents how is processed the data resulted from application of pulsed optical superficial treatments on surfaces of materials made of metal powders.

The parameters of the electrotechnological regime work are variable in the experimental program, namely the distance between the axis focal energy sources and surfaces play, the number of energy pulses applied to the voltage pulse of optical radiation, which causes a statistical analysis more complex, after which it will precise drawing lessons that will lead to a calculation microhardness model in the superificial layer of material.

\section{Keywords}

Surface treatments, optical radiation impulses, metal powder materials, microhardness

\section{Introduction}

Engineering sciences are currently preoccupied with finding materials with new economic processing technologies, modernization of equipment and machinery, etc., to meet the growing needs of the market more competitive in the market economy. These goals are the attention of researchers and specialists in most industries and scientific practical approach.

Technological advances have made remarkable achievements in these areas and significantly influenced the balance of forces in the development of new products and technologies (cost price, diversity, performance, etc.) between manufacturing firms under competitive market. These firms assimilate new technologies based on several criteria:

- Manufacturing cost;

- productivity;

- payback time;

- marketplace etc.

Therefore, the rational development of technologies should first consider the criteria of simplicity of installation and related equipment and minimal costs thereof.

The appearance of surface treatment methods and procedures by radiant energy required the development of plant and equipment, which now have the ability to confer high end parts properties (corrosion resistance, wear, fatigue, crushing etc.) by selective surfaces, without distorting adjacent 
areas controlled depths in areas difficult to reach with respect to restrictions ensure more precise heat treated area etc. These objectives can be achieved by using surface treatment plants using sources of electromagnetic energy concentrated in bundles and jets. Representative of this view are plasma treatment facilities, and the bunch electron beam of photons (laser). These sources are heating of songs performed with very high speed of over $103 \mathrm{deg} / \mathrm{s}$, practically unachievable with any other energy source.

The current level of technological development in the field of machine construction requires that the design and implementation of technologies and facilities for treatment of superficial energy radiating file following requirements:

$\checkmark$ to achieve the required temperature in a very short time;

$\checkmark$ the temperature in the workspace has to be as uniform as possible controlled with great precision, and the need to vary it according to a schedule;

$\checkmark$ higher energy efficiency;

$\checkmark$ higher productivity;

$\checkmark$ the occupied space to be as small as possible;

$\checkmark$ loading and unloading operations to be automated;

$\checkmark$ the construction to be as simple as possible, with low maintenance costs;

$\checkmark$ the protection of the environment and operators has to be ensured.

This paper addresses the issue of superficial treatments with electromagnetic fields, but with incoherent radiation sources are research oriented their application materials from metal powders.

They undertook a series of experimental research by studying and developing a broad theoretical base, surface treatments adapted to the specific application of ultrafast pulses of optical radiation on materials from metal powders $[3,4,5,6,7]$.

\section{Research Methods}

The following steps have been set for the conduct of the experimental research:

a) preparation of the surfaces of the parts subjected to the sperficial treatment;

b) preparation of the installation for the treatment;

d) identification of variables during the experiments and determining the working electrotehnologic regime;

c) conduct proper of the superficial treatment with radiation impulses;

d) sampling of the treated parts and of the control parts for making measurements and their preparation;

e) carrying out determinations of microstructure, roughness and microhardness.

The measurements were made with modern instrumentation, imaging results are evidenced by certificates metalographic and analysis reports.

Research results were highlighted in various scientific papers [1,2] and validated by experts in the field, namely leading manufacturer of sintered materials in the country SC Sinterom S.A. Cluj-Napoca, and by supporting the thesis named „Contributions for changes surface structure of materials sintered with electromagnetic fields".

\section{Statistical Processing of the Microhardness Results}

The statistical analysis was performed using research results and ZTEST TREND functions of Excel, they assessed the evolution of the results for the operating parameters that were not practical using and checking them by reference to the values of the blanks [8].

The results obtained in measuring the microhardness of the superficially treated parts are presented in tables no. 1 and table no. 2, being expressed in $\mathrm{HV}_{0,1}$ units. 
Table no. 1

\begin{tabular}{|c|c|c|c|c|c|}
\hline $\begin{array}{l}\text { Voltage and } \\
\text { impulse no }\end{array}$ & $\begin{array}{c}\text { Part } 1 \\
\mathrm{U}=1.8 \mathrm{kV}\end{array}$ & $\begin{array}{c}\text { Part 2 } \\
\mathrm{U}=1.9 \mathrm{kV}\end{array}$ & $\begin{array}{c}\text { Part 3 } \\
\mathrm{U}=\mathbf{2 . 0} \mathrm{kV}\end{array}$ & $\begin{array}{c}\text { Part } 4 \\
\mathrm{U}=2.1 \mathrm{kV}\end{array}$ & $\begin{array}{c}\text { Part } 5 \\
\mathrm{U}=2.2 \mathrm{kV}\end{array}$ \\
\hline $\begin{array}{c}\text { Group of } \\
\text { parts }\end{array}$ & $\mathbf{i}=\mathbf{1}$ & $\mathbf{i}=\mathbf{1}$ & $\mathbf{i}=\mathbf{1}$ & $\mathbf{i}=\mathbf{1}$ & $\mathbf{i}=\mathbf{1}$ \\
\hline $\begin{array}{c}\text { I } \\
\text { D BigUnpainted } \\
\text { IFP 800 }\end{array}$ & 0.338 & 0.219 & 0.430 & 0.446 & 0.469 \\
\hline $\begin{array}{c}\text { II } \\
\text { D }_{\text {BigPainted }} \\
\text { IFP } 800\end{array}$ & 0.201 & 0.107 & 0.337 & 0.345 & 0.365 \\
\hline $\begin{array}{c}\text { III } \\
\text { D }_{\text {BigUnpainted }} \\
\text { IFP } 2000\end{array}$ & 0.204 & 0.162 & 0.311 & 0.328 & 0.337 \\
\hline $\begin{array}{c}\text { IV } \\
\text { D }_{\text {BigPainted }} \\
\text { IFP 2000 } \\
\end{array}$ & 0.188 & 0.152 & 0.289 & 0.298 & 0.315 \\
\hline
\end{tabular}

Table no. 2

\begin{tabular}{|c|c|c|c|c|c|c|}
\hline $\begin{array}{c}\text { Impulse no. } \\
\text { Group of } \\
\text { parts }\end{array}$ & $\begin{array}{c}\text { Part 1 } \\
\mathbf{i}=1\end{array}$ & $\begin{array}{c}\text { Part } 2 \\
\mathbf{i}=2\end{array}$ & $\begin{array}{c}\text { Part } 3 \\
\mathbf{i}=\mathbf{3}\end{array}$ & $\begin{array}{c}\text { Part } 4 \\
\mathrm{i}=4\end{array}$ & $\begin{array}{c}\text { Part } 5 \\
\mathbf{i}=5\end{array}$ & $\begin{array}{c}\text { Part } 6 \\
i=6\end{array}$ \\
\hline $\begin{array}{c}\mathrm{V} \\
\mathrm{D}_{\text {BigUnpainted }} \\
\text { IFP } 800 \\
\mathrm{U}=2.0 \mathrm{kV}\end{array}$ & 333 & 342 & 327 & 323 & 321 & 326 \\
\hline $\begin{array}{c}\text { VI } \\
\mathrm{D}_{\text {BigUnpainted }} \\
\text { IFP } 800 \\
\mathrm{U}=2.2 \mathrm{kV}\end{array}$ & 298 & 303 & 296 & 298 & 296 & 290 \\
\hline $\begin{array}{c}\text { VII } \\
\text { D }_{\text {BigUnpainted }} \\
\text { IFP } 2000 \\
\mathrm{U}=2.0 \mathrm{kV}\end{array}$ & 460 & 478 & 477 & 467 & 464 & 462 \\
\hline $\begin{array}{c}\text { VIII } \\
\text { D }_{\text {BigUnpainted }} \\
\text { IFP 2000 } \\
\mathrm{U}=2,2 \mathrm{kV}\end{array}$ & 350 & 379 & 345 & 343 & 348 & 341 \\
\hline
\end{tabular}

Table no. 3 presents the microhardness values for the control samples, in two situations of the state of the surfaces of the examined parts, with or without black paint cover. After the measurements, we found the same value for both surfaces.

Table no. 3

\begin{tabular}{|c|c|}
\hline $\mathrm{D}_{\text {Big unpainted }}$ & $\mathrm{D}_{\text {BigPainted }}$ \\
\hline $246 \mathrm{HV}_{0,1}$ & $246 \mathrm{HV}_{0,1}$ \\
\hline
\end{tabular}


The estimation of the value of microhardness when the voltage increases to $\mathrm{U}=2.3 \mathrm{kV}$ and when the impulse number increases to 7 is studied.

Moreover, we formulate the hypothesis regarding the average value of microhardness compared to the value of the control sample when the part is not treated:

- the hypothesis $\bar{x}<\mathrm{x} \quad(\bar{x}$ is the selection average and $x$ is the value of the control sample, presented by the following
ZTEST figures) is acknowledged when the displayed $\mathrm{Z}$ test value is greater than $0.5-$ the critical value of the test, i.e. the average microhardness obtained is less than the microhardness obtained under normal conditions, without treatment.

The estimation of the microhardness at $2.3 \mathrm{kV}$ voltage for group of parts I (table no. 1), unpainted, at an energy of $800 \mathrm{~J}$, is shown in figure no. 1.

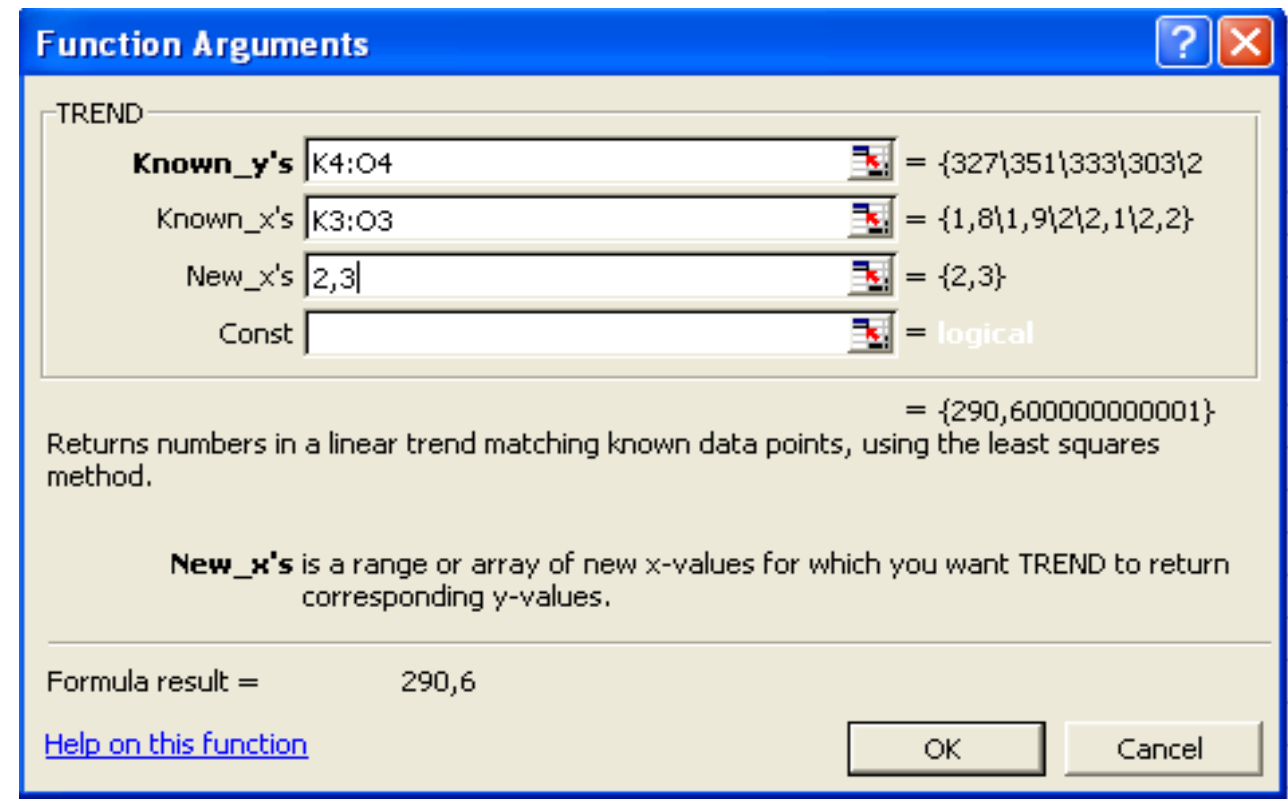

Figure no. 1 The estimation of the microhardness at $U=2.3 \mathrm{kV}$ for group of parts

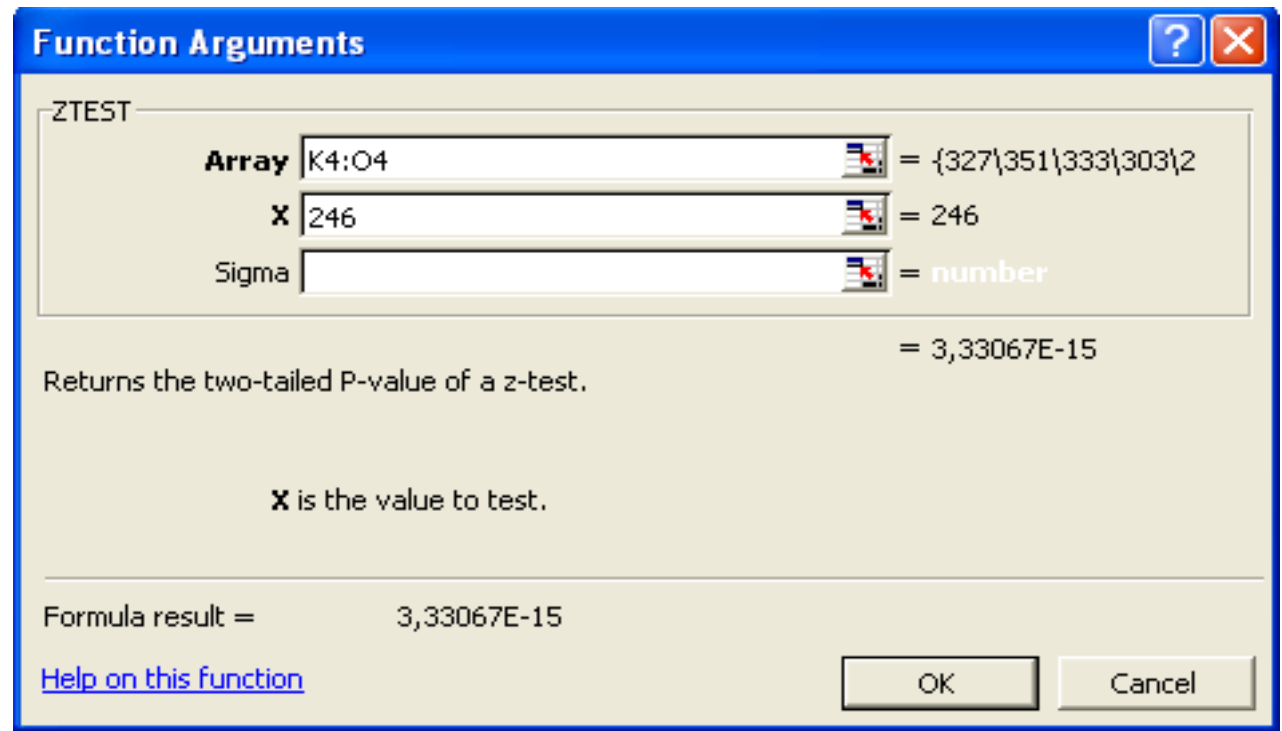

Figure no. 2 The ZTEST verification of microhardness for group of parts I 
One can notice that the optimum value of microhardness is at a voltage of $1.9 \mathrm{kV}$, after which the microhardness value decreases with the voltage increase.

The hypothesis $\bar{x}<246$ (control value) is not acknowledged (since the value of $\mathrm{Z}$ test is less than 0.5), i.e. the obtained microhardness average is greater than the microhardness obtained under normal conditions, without treatment (figure no. 2).
It is recommended that one should use these working conditions.

Figure no. 3 presents the microhardnesses obtained by means of the two types of lamps, 800 and $2000 \mathrm{~J}$, for the parts of groups II and IV (table no. 1), including microhardness value estimated at $2.3 \mathrm{kV}$. The graph presents the values for the painted surface of the samples.

\section{The microharhness obtained with $800 \mathrm{~J}$ and $2000 \mathrm{~J}$ energy lamps,}

on painted surfaces, distance lamp/piece $6 / 4 \mathrm{~mm}$

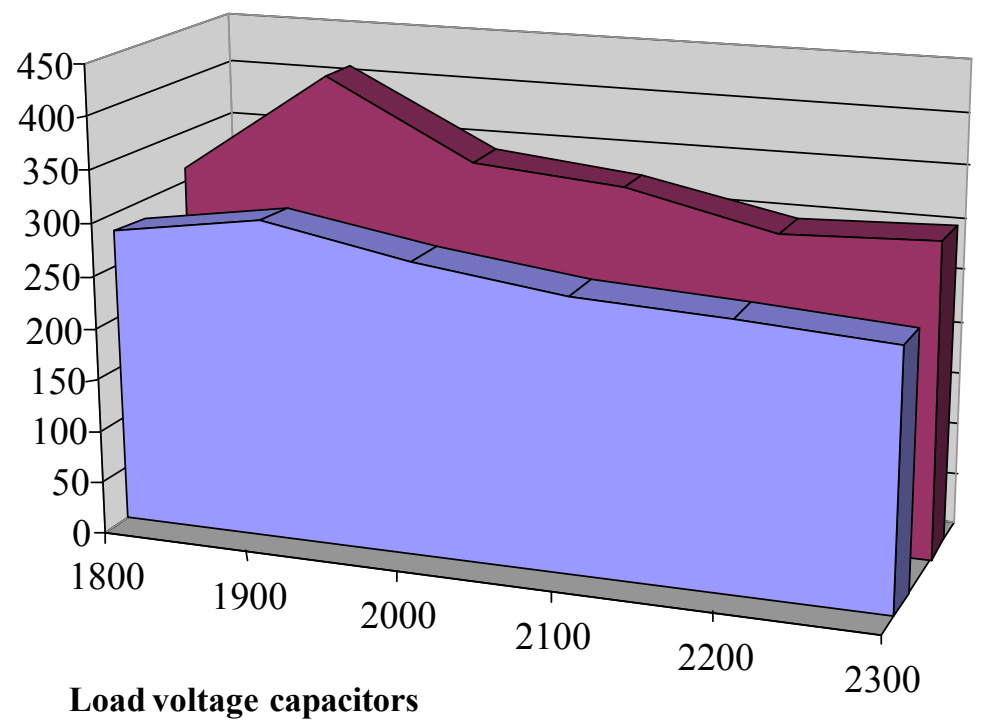

Figure no. 3 Microhardness obtained from the samples in groups II (painted) and IV (painted)

The sintered parts with a composition (0.6-1 \% C, 2-4\% Cu, and the rest iron) close to that of the studied samples $(0.72 \%$ $\mathrm{C}, 2.97 \% \mathrm{Cu}$, and the rest iron), which are subjected, after the sintering proper, to a hardening treatment, have a microhardness in the superficial layer of 320-370 HV.

In the case of superficial treatments with gas-discharge lamps, the amount of radiation emitted by them will be absorbed by the surface of the metallic material, heating it strongly, at a high speed of over $103 \mathrm{grd} / \mathrm{s}$, at temperatures above the line $\mathrm{A}_{\mathrm{c} 3}$ (iron carbon diagram).
In this field of temperatures the ferriticpearlitic structure will turn into a nonhomogeneous austenite structure which, in turn, due to the high speed of air cooling, will turn into hardened structures (martensite, bainite, etc.).

In figure no. 3 , the voltage regime of $1.9 \mathrm{kV}$ applied to both lamps, with better results for the IFP-2000 lamp, due to the amount of radiant energy 2.5 times greater than the radiant energy emitted by IFP-800 lamp is highlighted.

The slow decrease of the hardness in the case of voltage regimes higher than $2.0 \mathrm{kV}$, is 
due to instantaneous formation of partial melts in the superficial layer, with loss of carbon from the structure.

The type of surface coating, in the present case, black printing paint (containing carbon), has an influence on the increase of microhardness by the diffusion of carbon in the superficial pores of the surface of the part.

Comparing the results in figure no. 3 with those obtained in the case of unpainted samples, under the same working conditions, indicates that the microhardness of unpainted parts is greater than that of the painted ones. This can be explained by the appearance of larger quantities of residual austenite.

\section{Conclusions}

Statistical processing of results of research using the functions of the program TREND and ZTEST functions of Excel, who can predict the evolution of the results for the parameters that were not practical use within the experimental, but checking them by reference to witness evidence our values allow the formulation of the following conclusions regarding the modification of microhardness:

a) the microhardness changes in the superficial layer are due to the thermal action of the radiant field emitted by the lamps, which determines the increase of the temperature in the area in which the ferriticpearlitic structure will transform into a nonhomogeneous austenite structure which, in turn, due to the high speed of air cooling will turn into hardened structures;

b) at intensities higher than $10^{4} \mathrm{~W} / \mathrm{cm}^{2}$ of the energy emitted by the lamps, there appear superficial structural changes with the partial melting of the surface of the part, affecting the maximum microhardness values and the deterioration of the microgeometry of the surfaces of the parts;

c) the optimum voltage regime that was found is the one achieved by means of the IFP-2000 J lamp, $\mathrm{U}=2.0 \mathrm{kV}, \mathrm{i}=2$, the surface of the sample not covered with an absorbant substance;

d) by increasing the voltage from 2.0 $\mathrm{kV}$, one can notice a decrease of the microhardness explained by the absorption of a high amount of energy in the superficial layer, leading to the formation of partial melts, with loss of carbon from the structure;

e) when modifying the number of impulses, the maximum value of the microhardness is obtained at the second impulse, after which, with the increase of the number of impulses, there appears a microhardness decrease due to the same partial melts in the superficial layer;

f) when decreasing the distance between the lamp and the treated surface, the microhardness increases;

g) the microhardness values that were obtained recommend the use of the parts for fatigue, wear and contact pressure requirements. 


\section{Bibliography}

Virca, I. Tratamente superficiale cu câmpuri electromagnetice aplicate pieselor din pulberi metalice. Vol. I - Bazele teoretice ale aplicării tratamentelor superficiale ultrarapide asupra pieselor din pulberi metalice. Sibiu: Editura Academiei Forţelor Terestre, 2011.

Virca, I. Tratamente superficiale cu câmpuri electromagnetice aplicate pieselor din pulberi metalice. Vol. II - Aplicaţii practice ale tratamentelor cu impulsuri de radiaţii optice asupra pieselor din pulberi metalice. Sibiu: Editura Academiei Forţelor Terestre, 2011.

Virca, I. and Lazăr, V. Experimental research on the influence of superficial treatsments with optical radiation impulses on the microstructure of the surfaces of sintered parts. The 16th international conference „The Knowledge Based Organization”, Conference Proceedings 3, Land Forces Academy Publishing House, 25-27 november 2010, Sibiu, pp. 531-536.

Virca, I. and Căruţaşu, V. „Experimental research on the influence of superficial treatments with optical radiation impulses on the roughness of the surfaces of sintered parts". Buletinul ştiinţific nr. 2 (32), (Sibiu, 2011):178-182.

Virca, I. „Experimental studies on roughness and microhardness determination of some sintered parts, superficially treated with the optical radiation impulse". Revista Academiei Forţelor Terestre, vol XV, nr. 4 (60), (Sibiu, 2010): 495-502.

Virca, I. „The study of process sizes determining the durification of the sintered pieces with pulsed optiques radiations", Revista de tehnologii neconvenţionale $n r$. 1, (Timişoara, 2004): 83-84.

Virca, I. "The analyze of the final measures characterizing the durification process of the sintered pieces with pulsed optiques radiations", Revista de tehnologii neconvenţionale nr. 1, (Timişoara, 2004,): 84-85. 